\title{
Keanekaragaman Jenis Kantong Semar dan Penyebarannya di Taman Nasional Bukit Barisan Selatan, Bengkulu
}

\author{
Elyna Widiani ${ }^{*}$, Rian Perdana ${ }^{1}$, Muhammad Azhar Fakhri ${ }^{1}$, Fandy Muhammad ${ }^{1}$, Dirah Visda \\ Puja $^{1}$, Nurhalima Harahap ${ }^{1}$, Febrina Mawarti Andarini, Muhammad Abdul Aziz ${ }^{1}$, Hafidh Aqsa \\ Shahriza $^{1,}$ \& Ir. Edhi Sandra, M.Si ${ }^{2}$ \\ ${ }^{1}$ Rimbawan Pecinta Alam (RIMPALA), Fakultas Kehutanan, Institut Pertanian Bogor, Bogor 16680 \\ ${ }^{2}$ Departemen Konservasi Sumberdaya Hutan dan Ekowisata, Fakultas Kehutanan, Institut Pertanian \\ Bogor, Bogor 16680 \\ *korespondensi: elynawidiani@gmail.com
}

\begin{abstract}
ABSTRAK
Taman Nasional Bukit Barisan Selatan (TNBBS) merupakan habitat bagi jenis-jenis tumbuhan berbunga unik, salah satunya yaitu kantong semar. Kantong semar (Nepenthes sp.) merupakan tumbuhan karnivora pemangsa serangga yang dilindungi oleh pemerintah Indonesia dan termasuk ke dalam Appendiks II dalam CITES. Saat ini, data mengenai keanekaragaman jenis kantong semar dan persebarannya di TNBBS masih sangat minim, serta belum adanya penelitian mengenai kantong semar khususnya di Resort Muara Sahung. Penelitian ini bertujuan untuk mengidentifikasi keanekaragaman jenis dan sebaran kantong semar di Resort Muara Sahung, Taman Nasional Bukit Barisan Selatan, Kabupaten Kaur, Bengkulu. Serta menganalisis karakteristik habitatnya. Identifikasi jenis kantong semar dilakukan dengan melakukan perbandingan dengan literatur. Penentuan lokasi penelitian menggunakan metode purposive sampling dan dilakukan marking untuk mendapatkan data sebaran. Karakteristik habitat diidentifikasi dengan analisis vegetasi serta pengukuran komponen abiotik. Terdapat tiga jenis kantong semar yang teridentifikasi, yaitu Nepenthes gymnamphora, Nepenthes spathulata, dan Nepenthes ovate. Kantong semar tersebut tersebar di ujung utara Resort Muara Sahung pada ketinggian lebih dari $1700 \mathrm{~m}$ dpl. Karakteristik habitat kantong semar yang ditemukan di Resort Muara Sahung yaitu berada di ketinggian di atas $1700 \mathrm{~m}$ dpl, suhu $17,91{ }^{\circ} \mathrm{C}$, kelembaban $88,83 \%$, tutupan tanjuk 41,167\%, dan $\mathrm{pH}$ sebesar 5 .
\end{abstract}

Kata kunci: kantong semar, karakteristik habitat, Nepenthes, sebaran, Taman Nasional Bukit Barisan Selatan

\begin{abstract}
Bukit Barisan Selatan National Park (BBSNP) is a habitat for unique plants, one of them is pitcher plan. Pitcher plan (Nepenthes sp.).is a carnivorous plant which prey insect and is protected by the Indonesian government considered as Appendiks II in CITES. Currently, the data is still lack of data regarding the diversity species of Nepenthes $\mathrm{sp}$. and their distribution in BBSNP, and information regarding Nepenthes sp. in Muara Sahung Resort is still unknown. This study aimed to identify the species diversity, distribution, and habitat characteristics of Nephentes sp. in Muara Sahung Resort, Bukit Barisan Selatan National Park, Kabupaten Kaur, Bengkulu. Identification of Nepenthes sp. was conducted by comparing with the literature. Purposive sampling method was applied to determine the location of Nephentes sp. and marking is conducted to investigate its distribution. Habitat characteristics were identified by vegetation analysis and physical component measurements. The results revealed that there were three species of Nephentes sp. which identified e.g Nepenthes gymnamphora, Nepenthes spathulata, and Nepenthes ovate. These pitcher plants were spread at the northern tip of Muara Sahung Resort at altitude more than 1700 masl. Characteristics habitat


Nephentes sp. at Muara Sahung Resort are at altitude more that 1700 masl, temperature of $17.91{ }^{\circ} \mathrm{C}$, humidity of $88.83 \%$, slope cover of $41.167 \%$, and soil $\mathrm{pH}$ of 5 .

Keywords: pitcher plant, habitat characteristics, Nepenthes, distribution, Bukit Barisan Selatan National Park.

\section{PENDAHULUAN}

Pulau Sumatera dikenal sebagai habitat bagi flora dan fauna Indonesia, dan salah satu diantaranya adalah Bukit Barisan Selatan yang memiliki keanekaragaman hayati yang tinggi. Kawasan ini dikukuhkan sebagai Taman Nasional melalui Surat Pernyataan Menteri Pertanian No. 736/Mentan/X/ 1982, yang diperkuat melalui SK Menteri Kehutanan No. 185/Kpts-II/ 1997 tanggal 31 Maret 1997, dengan nama Taman Nasional Bukit Barisan Selatan (TNBBS). Kawasan hutan TNBBS seluas 356.800 ha membentang dari ujung selatan Provinsi Lampung hingga wilayah Provinsi Bengkulu bagian selatan.TNBBS dikenal sebagai rumah bagi berbagai tumbuhan unik, dan salah satu diantaranya yaitu kantong semar (Nepenthes sp.) yang dapattumbuh secara teresterial maupun epifit (Mansur, 2006). Tumbuhan ini mempunyai kemampuan memangsa serangga (insectivorous species/ pitcher plan) sehingga digolongkan sebagai tumbuhan karnivora. Pemangsaan tersebut merupakan mekanisme tersendiri bagi kantong semar untuk mengatasi keterbatasan hara yang ada dan umumnya hidup pada tanah miskin hara (Mardhiana et al, 2012). Kantong semar memiliki banyak jenis dan diantaranya merupakan tumbuhan yang dilindungi berdasarkan Undang-Undang No. 5 tahun 1990 dan Peraturan Pemerintah RI No. 7 tahun 1999, maupun termasuk Appendiks II dalam Convention on International Trade in Endangered Species (CITES, 2010).

Firstantinovi \&Karjono (2006) menyatakan bahwa terdapat 103 jenis kantong semar yang telah teridentifikasi dan dipublikasikan di dunia. Sebanyak 64 jenis diantaranya terdapat di Indonesia. Pulau Sumatera menempati posisi kedua sebagai pusat penyebaran kantong semar setelah Pulau Kalimantan dengan kekayaan 29 jenis kantong semar (Anwar et al., 2007). Menurut penelitian yang dilakukan oleh Ginting \& Lubis (2017) terdapat 13 jenis kantong semar di Tapanuli Selatan, Sumatera Utara. Nursanti \& Sri rahayu (2018) menemukan 3 jenis kantong semar di Kawasan Hulu Air Lempur Kecamatan Gunung Raya Kabupaten Kerinci. Muhaimin et al., (2018) menemukan 2 jenis kantong semar yaitu Nepenthes spathulata dan Nepenthes gymnamphora di kawasan Hutan Lindung Gunung Tanggamus, Lampung. Minimnya data mengenai keanekaragaman kantong semar dan persebarannya di TNBBS serta belum adanya penelitian kantong semar di Resort Muara Sahung menjadi latar belakang dilakukannya penelitian ini. Penelitian ini bertujuan untuk mengidentifikasi keanekaragaman jenis, sebaran, dan karakteristik habitat kantong semar di Resort Muara Sahung TNBBS. Data yang diperoleh dapat menjadi informasi bagi upaya konservasi kantong semar serta menjadi masukan bagi pihak pengelola dalam rangka pengelolaan tumbuhan ini secara berkelanjutan.

\section{METODE}

Penelitian dilaksanakan di Resort Muara Sahung TNBBS, Kabupaten Kaur, Provinsi Bengkulu. Penelitian dilaksanakan pada bulan Juli-Agustus 2017. Data yang diambil meliputi jenis, sebaran dan karakteristik habitat kantong semar.

Lokasi penelitian ditentukan dengan menggunakan metode purposive sampling berdasarkan informasi dari petugas TNBBS berupa koordinat-koordinat lokasi yang berpotensi ditemukannya kantong semar. Purposive sampling adalah teknik penentuan sampel dengan pertimbangan tertentu (Sugiyono,2012). Untuk menuju lokasi potensial tersebut digunakan jalur eksplorasi yang menghubungkan antar titik koordinat. Lokasi ditemukannya kantong semar ditandai (marking) menggunakan GPS. Jenis kantong semar yang ditemukan pada jalur eksplorasi, diidentifikasi dengan cara dicocokkan dengan buku Nepenthes: Kantong Semar Yang Unik (Mansur, 2006). Selain itu, jumlah individu kantong semar juga dihitung berdasarkan jenisnya. Jenis kantong semar yang belum teridentifikasi didokumentasikan, kemudian diidentifikasi di Pusat Penelitian Biologi-LIPI Cibinong. 
Pengambilan data karakteristik habitat kantong semar dilakukan dengan analisis vegetasi, pengukuran $\mathrm{pH}$ dan KTK tanah, pengukuran suhu dan kelembapan udara, pengukuran tutupan tajuk, serta ketinggian lokasi. Analisis vegetasi dilakukan dengan pembuatan plot petak kuadrat pada lokasi ditemukannya kantong semar di jalur eksplorasi. Pengambilan data dalam petak kuadrat berdasarkan tingkatan tumbuhan yang ada di dalamnya, yaitu semai, pancang, tiang, dan pohon. Data yang diambil berupa jenis, jumlah individu, dan diameter. Petak berukuran $20 \times 20 \mathrm{~m}$ untuk kantong semar dan pohon dengan batang berdiameter $\geq 20 \mathrm{~cm}$. Petak berukuran $10 \times 10 \mathrm{~m}$ untuk tiang dengan batang berdiameter 10-20 cm. Petak berukuran $5 \times 5 \mathrm{~m}$ untuk pancang, yaitu anakan dengan dengan tinggi > $1,5 \mathrm{~m}$ dan diameter setinggi dada $<10 \mathrm{~cm}$. Petak ukuran $2 \times 2 \mathrm{~m}$ untuk tumbuhan bawah dan semai, yaitu anakan dengan tinggi $\leq 1,5 \mathrm{~m}$. Derajat keasaman $(\mathrm{pH})$ merupakan nilai yang menunjukkan aktivitas ion hidrogen dalam air, sedangkan Kapasitas Tukar Kation (KTK) atau Cation Exchange Capacity (CEC) merupakan jumlah total kation yang dapat dipertukarkan pada permukaan koloid yang bermuatan negatif (Hardjowigeno, 2007). Pengukuran $\mathrm{pH}$ dilakukan dengan menggunakan $\mathrm{pH}$ indicator universal, sedangkan untuk menentukan Kapasitas Tukar Kation (KTK) dilakukan dengan mengambil sampel tanah pada empat bagian ujung dan tengah plot yang diambil pada setiap plot. Setelah sampel tanah diambil, semua tanah yang berada pada satu plot dicampur dengan air pada botol dan diendapkan untuk mendapatkan nilai KTK. Pengukuran suhu dan kelembaban dilakukan dengan menggunakan termometer dry and wet pada setiap plot penelitian selama 15 menit. Persentase tutupan tajuk pada masing-masing plot ditentukan dengan menggunakan densiometer. Penggunaannya adalah dengan mengarahkan cermin yang dilengkapi grid di densiometer pada arah datangnya cahaya yang kemudian dihitung area bayangan tajuknya.

\section{Analisis Data}

Data hasil analisis vegetasi di lapang dihitung nilai Indeks Nilai Penting (INP). INP ini digunakan untuk menetapkan dominasi suatu jenis terhadap jenis lainnya. INP menggambarkan kedudukan ekologis suatu jenis dalam komunitas. INP dihitung berdasarkan penjumlahan nilai Kerapatan Relatif (KR), Frekuensi Relatif (FR) dan Dominansi Relatif (DR) (Mueller-Dombois dan Ellenberg, 1974).

$$
\begin{aligned}
& \text { Kerapatan }=\frac{\text { Jumlah individu suatu jenis }}{\text { Luas plot }} \\
& \text { Kerapatan Relatif }(\mathrm{KR})=\frac{\text { Kerapatan suatu jenis }}{\text { Kerapatan seluruh jenis }} \times 100 \% \\
& \text { Frekuensi }=\frac{\text { Jumlah subplot ditemukan suatu jenis }}{\text { Jumlah seluruh subplot pengamatan }} \\
& \text { Frekuensi Relatif }(\mathrm{FR})=\frac{\text { Frekuensi suatu jenis }}{\text { Frekuensi seluruh jenis }} \times 100 \% \\
& \text { Dominansi }=\frac{\text { Jumlah luas bidang dasar suatu jenis }}{\text { Luas area sampel }} \\
& \text { Dominansi Relatif }(\mathrm{DR})=\frac{\text { Dominansi suatu jenis }}{\text { Dominansi seluruh jenis }} \times 100 \% \\
& \text { INP (Semai, Pancang })=(\mathrm{KR})+(\mathrm{FR}) \\
& \text { INP }(\text { Tiang, Pohon })=(\mathrm{KR})+(\mathrm{FR})+(\mathrm{DR})
\end{aligned}
$$




\section{HASIL DAN PEMBAHASAN}

\section{Keanekaragaman Jenis Kantong Semar}

Berdasarkan hasil penelitian, terdapat tiga jenis kantong semar di Resort Muara Sahung TNBBS, yaitu Nephentes gymnamphora, Nepenthes spathulata, dan Nepenthes ovate. Total individu yang ditemukan yaitu sebanyak 106 individu kantong semar. Ketiga jenis tersebut ditemukan pada ketinggian di atas $1.700 \mathrm{~m}$ dpl. Jumlah individu dan INP per jenis kantong semar yang ditemukan dapat dilihat pada Tabel 1 .

Tabel 1.Daftar jenis, jumlah, dan INP kantong semar

\begin{tabular}{clcc}
\hline No & \multicolumn{1}{c}{ Jenis } & Jumlah & INP(\%) \\
\hline 1. & Nepenthes gymnamphora & 101 & 190,57 \\
2. & Nepenthes spathulata & 3 & 5,66 \\
3. & Nepenthes ovata & 2 & 3,77 \\
\hline
\end{tabular}

\section{Nepenthes gymnamphora}

Nepenthes gymnamphora merupakan jenis kantong semar yang paling umum diantara ketiga jenis yang ditemukan, yaitu dengan INP sebesar 190,57\%. Nepenthes gymnamphora melimpah dan tersebar merata karena kondisi lingkungan di Resort Muara Saung sesuai dengan karakteristik tempat tumbuh Nepenthes gymnamphora, yaitu beradapada ketinggian 600-2.800 m dpl, toleran terhadap cahaya, dan kelembaban tinggi (Clarke, 2001). Resort Muara Sahung yang menjadi habitat Nepenthes gymnamphora memiliki rata-rata kelembapan 88,83\% dengan kondisi tanah kurang subur ber-pH 5 . Sesuai dengan pendapat Mansur (2006), yang menyatakan bahwa keberadaan Nepenthes gymnamphora menunjukkan curah hujan suatu kawasan cukup tinggi, kelembapan diatas $75 \%$ dan tanahnya miskin unsur hara.

Ciri-ciri Nepenthes Gymnaphora menurut Mansur (2006) yaitu berwarna merah dengan bercak-bercak kekuningan dan panjangnya mencapai $15 \mathrm{~cm}$, lebarnya $5 \mathrm{~cm}$. Handoyo \& Sitanggang (2006) menyebutkan morfologi Nepenthes gymnamphora yaitu panjang batangnya $\leq 15 \mathrm{~cm}$ dengan diameter $\leq 7 \mathrm{~mm}$ berbentuk silinder dengan panjang ruas daun $\leq 10 \mathrm{~cm}$. Kantong semar jenis ini mempunyai daun yang tebal, bertangkai lanset, panjang daun $\leq 30 \mathrm{~cm}$, lebar daun $\leq 6 \mathrm{~cm}$ dengan panjang sulur $\leq 23 \mathrm{~cm}$. Kantong roset dan kantong bawahnya berbentuk oval dengan warna merah keunguan yang memiliki panjang $\leq 12 \mathrm{~cm}$ dan lebar $4 \mathrm{~cm}$ serta memiliki dua sayap. Kantong atas Nepenthes gymnamphora berbentuk pinggang, memiliki warna hijau dengan lurik merah, tinggi $\leq 18$ $\mathrm{cm}$ dan lebar $\leq 5 \mathrm{~cm}$, tanpa sayap dengan penutup bundar yang berukuran $4 \times 4,5 \mathrm{~cm}$. Perbungaan Nepenthes gymnamphora berbentuk tandan yang panjangnya $\leq 30 \mathrm{~cm}$ serta sepal berbentuk lonjong dengan panjang $\leq 5 \mathrm{~mm}$, perbungaan betina lebih pendek dari pada jantan.

Persebaran Nepenthes gymnamphora di Indonesia paling banyak ditemukan di Pulau Jawa, yaitu di daerah pegunungan Jawa Barat dan Jawa Tengah, dan sebagian kecil Jawa Timur, pada ketinggian antara 900-2.400 m dpl. Selain Pulau Jawa, kantong semar jenis ini hanya ditemukan di Pulau Sumatera (Mansur, 2002). Menurut IUCN, status Nepenthes gymnamphora temasuk ke dalam Least Concern, yaitu spesies yang telah dievaluasi namun tidak termasuk ke dalam kategori mana pun. Spesies-spesies tersebut tidak termasuk ke dalam spesies terancam, mendekati terancam punah atau ketergantungan konservasi. Berdasarkan CITES, Nepenthes gymnamphora termasuk ke dalam Appendiks II. Appendiks II merupakan daftar spesies yang tidak terancam punah, tetapi mungkin akan terancam punah apabila perdagangan terus berlanjut tanpa adanya pengaturan. 


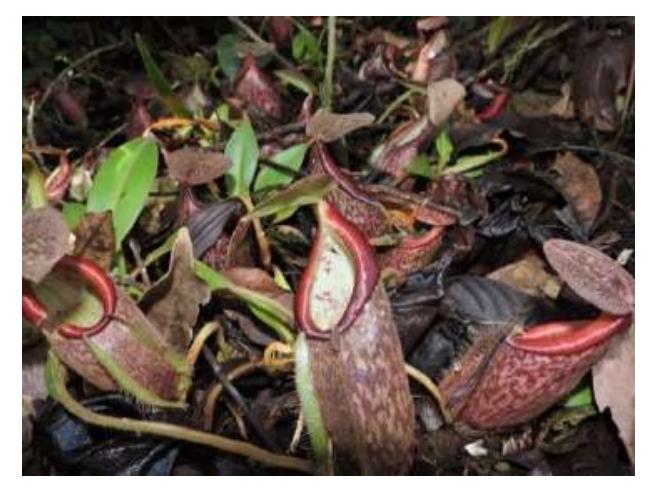

Gambar 1.Nepenthes gymnamphora (Sumber:RIMPALA)

\section{Nepenthes spathulata}

Menurut Clarke (2001) jenis ini tumbuh secara terestrial dan berperawakan epifit pada hutan berlumut dan puncak pegunungan pada ketinggian 1.100-2.900 $\mathrm{m}$ dpl. Lebih lanjut dikatan bahwa Nepenthes spathulata dijumpai tumbuh secara terestrial di kawasan Gunung Talang yang tidak aktif, pada ketinggian $1.800 \mathrm{~m}$ dpl (Puspitaningtyas dan Wawaningrum 2007). Nepenthes spathulata yang ditemukan dalam penelitian ini memiliki INP sebesar 5,66 \%, yang berarti tidak dominan jika dibandingkan dengan Nepenthes gymnamphora. Kondisi hutan pegunungan Resort Muara Sahung yang lembab pada ketinggian $1700 \mathrm{~m}$ dpl seharusnya mendukung pertumbuhan jenis ini. Hal itu disebabkan karena jenis ini tumbuh secara terestrial maupun epifit di tempat berlumut, terbuka, dan bersemak seperti pernyataan Clarke (2001). Jenis Nepenthes spathulata dilindungi oleh pemerintah Indonesia melalui peraturan menteri lingkungan hidup dan kehutanan nomor 92.

Menurut Mansur (2006), Nepenthes spathulata memiliki batang yang memanjat dengan diameter $0,8 \mathrm{~cm}$ dan berbentuk silindris-bersegi. Bentuk daunnya tebal, duduk atau bertangkai semu, bentuk sudip-bundar telur terbalik, tepi daunnya bergelombang dengan panjang $15-20 \mathrm{~cm}$ dan lebar 5$7 \mathrm{~cm}$. Ujung daun melingkar, pucuknya runcing atau terbelah dua serta memiliki sulur dengan panjang $17-20 \mathrm{~cm}$. Kantong bawah pada jenis kantong semar ini tidak berkelompok di dekat permukaan tanah dan tidak pernah pada tangkai daun yang tereduksi. Bagian bawah Nepenthes spathulata berbentuk bulat telur dan bagian atasnya menyempit seperti tabung/silindris dan agak melebar di dekat mulut. Panjang kantong sebesar 23-30 cm, lebar $10 \mathrm{~cm}$ dengan warna hijau kemerahan. Nepenthes spathulata bersayap dua, memanjang setinggi kantong dengan lebar $2,5 \mathrm{~cm}$ dan berambut. Mulut kantong melingkar bundar telur atau jorong, meninggi dan menyempit di bagian pangkal dengan lebar $2-4 \mathrm{~cm}$ dan panjang 6-7 cm. Tutupnya bentuk bundar telur atau menjantung. Kantong atas pada Nepenthes spathulata jarang terbentuk, bentuknya menyerupai perut buncit pada 1/4-1/3 bagian bawah dan silindris di bagian atasnya. Panjang kantong pada Nepenthes spathulata sebesar $15 \mathrm{~cm}$ dengan lebar sebesar $3 \mathrm{~cm}$. Mulut kantong melingkar dan agak serong. Nepenthes spathulata memiliki peristom dengan lebar $0,7 \mathrm{~cm}$, tutup bundar telur agak melebar dan taji bercabang. Perbungaannya tandan, panjang gagang perbungaan $20 \mathrm{~cm}$, perhiasan bunga bentuk bundar - jorong dengan panjang $5 \mathrm{~mm}$, struktur perbungaan betina menyerupai jantan.

Persebaran Nepenthes spathulata meliputi Pulau Sumatera antara lain Jambi, Bengkulu, Sumatera Selatan dan Lampung (Clarke, 2001). Nepenthes spathulata termasuk ke dalam status Vulnerable menurut IUCN, yaitu status konservasi yang diberikan kepada spesies yang sedang menghadapi resiko kepunahan di alam liar pada waktu yang akan datang. Berdasarkan CITES, Nepenthes spathulata termasuk ke dalam Appendiks II yaitu daftar spesies yang tidak terancam punah, tetapi mungkin terancam punah apabila perdagangan terus berlanjut tanpa adanya pengaturan. 


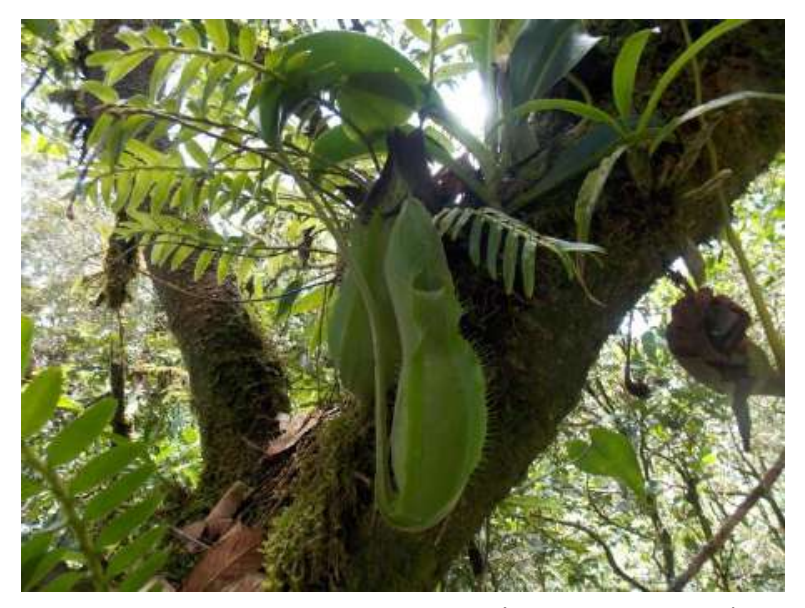

Gambar 2. Nepenthes spathulata (Sumber:RIMPALA)

\section{Nepenthes ovata}

Nepenthes ovata ditemukan tumbuh secara teresterial, terkadang ditemukan juga tumbuh secara epifit di Resort Muara Sahung TNBBS di ketinggian lebih dari $1.700 \mathrm{~m}$ dpl. Menurut Clarke (2001) Nepenthes ovata dapat hidup secara teresterial dan epifit di hutan lumut pada ketinggian 1.700$2.100 \mathrm{~m}$ dpl. Nepenthes ovata yang ditemukan dalam penelitian ini memiliki INP sebesar 3,77 \%, yang berarti tidak melimpah jika dibandingkan dengan Nepenthes gymnaphora. Hal ini disebabkan Nepenthes ovata ditemukan pada ketinggian lebih dari $1.700 \mathrm{~m}$ dpl. Lebih lanjut dalam penelitian Fadillah et al., (2014) keanekaragaman Nepenthes pada kawasan kebun bonsai dan sekitarnya di Cagar Alam Dolok Sibual-Buali, Sumatera Utara jenis Nepenthes ovata dijumpai pada ketinggian 1.400$1.500 \mathrm{~m}$ dpl. Menurut IUCN, status Nepenthes ovata termasuk ke dalam Least Concern (Clarke 2018) yang berarti telah dievaluasi berdasarkan tingkat risiko dan tidak memenuhi syarat sebagai kategori kritis, rentan, maupun genting saat ini. Berdasarkan CITES, Nepenthes ovata termasuk ke dalam Appendiks II. Appendiks II merupakan daftar spesies yang tidak terancam kepunhan, tetapi mungkin terancam punah apabila perdagangan terus berlanjut tanpa adanya pengaturan.

Ciri-ciri Nepenthes ovata menurut Clarke (2001) yaitu pada anakan batang tumbuh roset dan pada dewasa batang tumbuh memanjat. Bentuk batang silindris berwarna hijau kecoklatan dengan permukaan batang licin. Daun-daun tunggal, tidak ber-petiole, melingkar pada batang, susunan daun alternate, bentuk obovate, warna daun hijau kemerahan dan hijau tua, permukaan daun licin. Ibu tulang daun jelas dengan warna hijau kemerahan, tepi daun berbulu halus. Sulur berwarna coklat di bagian dekat daun, hijau di bagian tengah dan merah di bagian dekat kantung, permukaan sulur berbulu halus. Kantung bawah warna coklat kemerahan sampai merah kehitaman, bagian dalam terdapat bintik merah, bentuk elips di bagian bawah dan membesar silindris ke bagian atas, bersayap dengan bulu rapat, panjang bulu 0,1-1,1 cm. Pinggir mulut kantungnya berwarna merah tua atau merah menyala, melingkar oval, semakin meninggi di bagian belakang, semakin melebar ke atas di kedua sisi dengan lebar mencapai 3,5 cm. Berbentuk sangat lebar dan melengkung ke bagian belakang dan di bagian depan terdapat tonjolan sepanjang $0,2 \mathrm{~cm}$. Bentuk tutup kantung bulat telur, membulat di bagian ujung dan berlekuk di bagian pangkal, warna kuning dengan berurat merah, di bagian bawah tutup kantung terdapat tonjolan seperti kail sepanjang $0,4 \mathrm{~cm}$ berwarna merah atau hitam, taji bercabang dua berwarna cokelat. Kantung atas berwarna hijau kekuningan, bagian dalamnya terdapat bintik merah. Kantung berbentuk corong dengan mulut lebar yang mendongak ke atas. Pinggir mulut kantung berwarna hijau dengan liris merah, melingkar bulat, semakin meninggi di bagian belakang, semakin melebar ke atas dengan lebar mencapai $1,8 \mathrm{~cm}$. Berbentuk melengkung ke bagian belakang dan di bagian depan terdapat tonjolan sepanjang $0,5 \mathrm{~cm}$. Pinggir mulut kantung rapat dan sangat jelas seperti duri melengkung ke bagian dalam kantung dan pinggir mulut kantung yang tepat di bawah tutup kantung menjarang dan semakin jelas dan panjang. Bentuk tutup kantung bulat telur, membulat di bagian ujung dan berlekuk di bagian pangkal, warna kuning, di bagian bawah tutup kantung terdapat tonjolan seperti kail sepanjang $0,8 \mathrm{~cm}$ berwarna hijau kekuningan, taji bercabang dua berwarna cokelat atau hijau. 


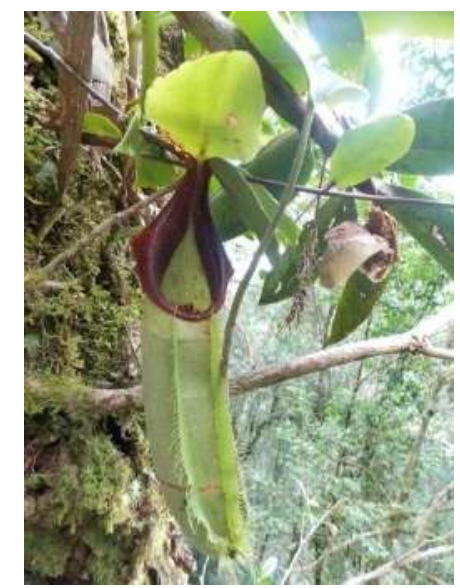

Gambar 3.Nepenthes ovata (Sumber:RIMPALA)

Berdasarkan jumlah komposisi jenis kantong semar yang ditemukan pada masing-masing habitat terdapat perbedaan jumlah dan jenisnya, perbedaan komposisi ini karena adanya perbedaan tempat tumbuh oleh kondisi habitat antara lain vegetasi, suhu, kelembaban, intesitas cahaya matahari. Haryani (1999) menyatakan bahwa pertumbuhan dan perkembangan yang cepat terjadi pada kondisi lingkungan yang optimal dan adanya kesesuaian habitat. Menurut Odum (1993) bahwa suatu jenis dapat dikatakan dominan apabila jenis yang bersangkutan terdapat dalam jumlah yang besar, tersebar merata pada suatu daerah. selain itu jenis ini juga hidup di kawasan atau areal yang memiliki sedikit unsur hara seperti jenis kantong semar lain pada umumnya.

\section{Sebaran Jenis Kantong Semar}

Berdasarkan hasil penelitian di Resort Muara Sahung TNBBS terdapat beberapa titik sebagai lokasi ditemukannya tumbuhan kantong semar. Titik-titik tersebut berada pada ketinggian lebih dari $1.700 \mathrm{~m}$ dpl dengan suhu sebesar $19^{\circ} \mathrm{C}$ dan kelembaban sebesar 88,3\%. Kantong semar tersebar di ujung utara Resort Muara Sahung yang berbatasan langsung dengan wilayah Provinsi Sumatera Selatan. Sebaran kantong semar semakin padat dari arah barat ke arah timur. Nepenthes gymnamphora ditemukan selalu berkelompok dan jarang individu berada terpisah dari komunitas. Hal itu berarti bahwa Nepenthes gymnamphora telah mendominasi wilayah tersebut. Nepenthes spathulata hanya ditemukan di 2 titik dan 1 titik pada Nephentes ovata. Sedikitnya jumlah individu kedua jenis tersebut menandakan tingkat kepadatan Nepenthes spathulata dan Nephentes ovate lebih rendah dibandingkan dengan Nepenthes gymnamphora. Peta sebaraan kantong semar disajikan pada gambar 4.

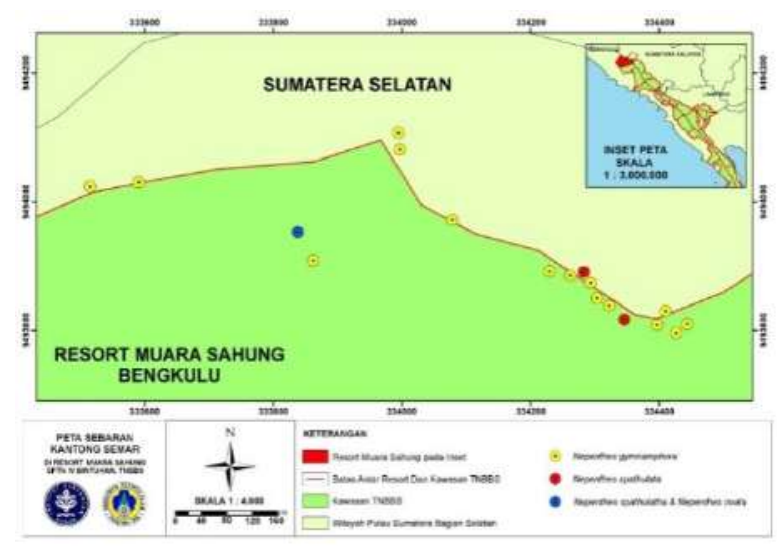

Gambar 4. Peta sebaran kantong semar (Sumber:RIMPALA) 


\section{Karakteristik Habitat Kantong Semar}

\section{Komponen Abiotik}

Suhu rata-rata selama penelitian berkisar antara $17^{\circ} \mathrm{C}-21,3^{\circ} \mathrm{C}$ untuk suhu kering dan $16^{\circ} \mathrm{C}$ $20^{\circ} \mathrm{C}$ untuk suhu basah dengan kelembaban udara sebesar $84 \%-93,3 \%$. Suhu yang baik untuk kantong semar yang hidup di dataran rendah yaitu sekitar $20-35^{\circ} \mathrm{C}$, sedangkan untuk kantong semar yang hidup di dataran tinggi sekitar $10-30^{\circ} \mathrm{C}$, namun ada pula beberapa jenis kantong semar yang menghendaki suhu rendah hingga $4^{\circ} \mathrm{C}$ untuk tumbuh dengan baik. Tingkat kelembaban yang memungkinkan untuk hidupnya kantong semar yaitu $>70 \%$, jika kelembapan terlalu rendah maka dipastikan kantong semar yang tumbuh tidak akan membentuk kantong dan tidak tumbuh dengan baik (Mansur, 2006).

Hasil pengukuran $\mathrm{pH}$ tanah yang diperoleh yaitu $\mathrm{pH}$ sebesar 5 dengan kapasitas tukar kation yang sedang. Hal tersebut sesuai dengan Wiryono (2009) yang menyatakan bahwa karakteristik tanah yang menjadi habitat tumbuh kantong semar umumnya memiliki unsur hara dan nitrogen yang rendah dan bersifat asam dengan kisaran $\mathrm{pH}$ 4-7.

Tutupan tajuk di Resort Muara Sahung termasuk dalam kategori sedang yaitu sebesar 41,167\%. Menurut Carolyn et al., (2013) terdapat 4 kelas kerapatan tajuk, yaitu kategori hutan kerapatan tajuk (0-10\%), kerapatan rendah (11-30\%), kerapatan sedang (31-50\%), dan kerapatan tinggi (51-100\%). Kebutuhan kantong semar terhadap cahaya matahari berbeda beda tergantung jenisnya, intensitas cahaya 50\% yang diterima tanaman, umumnya sangat baik untuk semua jenis kantong semar (Mansur, 2006). Sebagian kantong semar membutuhkan cahaya matahari secara langsung dan sebagian lagi tidak, namun umumnya semua tanaman yang mendapat cahaya matahari yang cukup baik secara langsung maupun tidak langsung dapat tumbuh dengan baik.

\section{Komponen Biotik}

Komposisi dan struktur vegetasi habitat kantong semar diperoleh dari hasil analisis vegetasi selama di lapang. Terdapat 14 plot di sepanjang jalur eksplorasi. Jenis tumbuhan yang mendominasi terhadap jenis lainnya dilihat dari hasil indeks nilai penting, indeks ini berfungsi untuk menggambarkan kedudukan ekologis suatu jenis dalam komunitas (Indriyanto, 2006). Indeks nilai penting vegetasi tertinggi setiap tingkat permudaan disajikan pada tabel 2.

Tabel 2.Indeks Nilai Penting (INP) vegetasi tertinggi

\begin{tabular}{|c|c|c|c|}
\hline $\begin{array}{c}\text { Tingkat } \\
\text { Permudaan }\end{array}$ & $\begin{array}{l}\text { Nama } \\
\text { lokal }\end{array}$ & $\begin{array}{l}\text { Nama } \\
\text { ilmiah }\end{array}$ & $\begin{array}{l}\text { INP } \\
(\%)\end{array}$ \\
\hline \multirow{3}{*}{ Semai } & Loquat & $\begin{array}{c}\text { Eriobotrya } \\
\text { japonica }\end{array}$ & 28,03 \\
\hline & Merambung & $\begin{array}{c}\text { Vernonia } \\
\text { arborea }\end{array}$ & 19,74 \\
\hline & Begonia & Begonia sp & 18,07 \\
\hline \multirow{3}{*}{ Pancang } & Rotan & $\begin{array}{l}\text { Calamus } \\
\text { axillaria }\end{array}$ & 109,00 \\
\hline & Karet Kebo & $\begin{array}{c}\text { Ficus } \\
\text { Elastic }\end{array}$ & 13,30 \\
\hline & Kelat & $\begin{array}{l}\text { Syzygium } \\
\text { sp. }\end{array}$ & 11,20 \\
\hline \multirow{3}{*}{ Tiang } & Pasang & $\begin{array}{c}\text { Lythocarpus } \\
\mathrm{sp}\end{array}$ & 56,05 \\
\hline & Kelat & $\begin{array}{l}\text { Syzygium } \\
\text { sp. }\end{array}$ & 39,01 \\
\hline & Jamblang & $\begin{array}{l}\text { Syzygium } \\
\text { cumini }\end{array}$ & 32,10 \\
\hline Pohon & Pasang & $\begin{array}{l}\text { Lithocarpus } \\
\text { sp. }\end{array}$ & 106,93 \\
\hline
\end{tabular}

Pusat Penelitian Biologi, lembaga IImu Pengetahuan Indonesia | 155 


\begin{tabular}{|c|c|c|}
\hline $\begin{array}{c}\text { Pasak } \\
\text { kurung }\end{array}$ & $\begin{array}{l}\text { Eurycoma } \\
\text { longifolia }\end{array}$ & 80,75 \\
\hline Medang & $\begin{array}{l}\text { Dehaasia } \\
\text { cuneate }\end{array}$ & 25,53 \\
\hline
\end{tabular}

Jenis tumbuhan yang melimpah pada tingkat tiang yaitu pasang (Lythocarpus sp), kelat (Syzigium sp.), dan jamblang (Syzigium cumini) Terdapat beberapa jenis tumbuhan tingkat pohon yang mendominasi yaitu, Medang (Dehaasia cuneate), pasak kurung (Eurycoma longifolia), dan pasang (Lithocarpus $s p$ ). Pasang (Lithocarpus sp.) menyukai hidup di tanah yang agak basah seperti di aliran pinggir sungai dan genangan air pada ketinggian 50 sampai $1800 \mathrm{~m}$ dpl. Pasang (Lithocarpus $s p$.) memiliki tajuk yang cukup rapat, sehingga intensitas cahaya yang masuk sebesar $50 \%$. Intensitas cahaya sebesar $50 \%$ mempengaruhi tumbuhan yang berada disekitar pohon pasang, salah satunya yaitu kantong semar. Intensitas cahaya yang di butuhkan kantong semar adalah 50\% (Mansur 2006).

\section{UCAPAN TERIMAKASIH}

Terimakasih penulis ucapkan kepada Balai Besar Taman Nasional Bukit Barisan Selatan (TNBBS) yang telah bekerja sama dan memfasilitasi penelitian ini, khususnya kepada Bapak Uga Yogaswara dan Bapak Agus Sulaeman yang telah mendampingi pengambilan data di lapang, kepada WWF yang telah membantu transportasi dan pengambilan data selama di lapang, khususnya Mas Ari dan Mas Dedi. Terimakasih juga diucapkan kepada keluarga besar Rimbawan Pecinta Alam Fahutan IPB, khususnya Tim Ekspedisi Nephentes Kantong Serawai dan SC, serta semua pihak yang tidak dapat ditulis satu persatu.

\section{DAFTAR PUSTAKA}

Anwar, F., A. Kunarso dan T. S. Rahman. 2007. Kantong Semar (Nepenthes sp.) di Hutan Sumatera, tanaman unik yang langka. Dalam: Prosiding ekspose hasil hasil penelitian.Padang, 20 September 2006.pp 173-181.

Carolyn, R. D., Baskoro, P.T., Prasetyo, L. B. 2013. Analisis Degradasi untuk Penyusunan arahan Strategi Pengendaliannya di Taman Nasional Gunung Halimun Salak Provinsi Jawa Barat. Jurnal Globe. 15(1): 39-47.

CITES. 2010. Convention on International Trade In Endangered Species Of Wild Fauna And Flora. Appendices I, II \& III. Tersedia pada https://cites.org/sites/default/files/eng/app/2017/EAppendices-2017-04-04.pdf. Diakses pada tanggal 5 Januari 2018.

Clarke, C. 2001. Nepenthes of Sumatra and Peninsular Malaysia. Kinabalu: Natural History publication (Borneo).

Clarke, C., Cantley, R., Nerz, J., Rischer, H., Witsuba, A. 2000.Nepenthes gymnamphora.The IUCN Red List of Threatened Species 2000.Tersedia pada: http://dx.doi.org/10.2305/IUCN.UK.2000.RLTS.T39664A10249370.en.Diakses pada tanggal17 Oktober 2017.

Clarke, C., Cantley, R., Nerz, J., Rischer, H., Witsuba, A. 2000.Nepenthes ovata.The IUCN Red List of Threatened 2000.[Internet].Tersedia pada: http://dx.doi.org/10.2305/IUCN.UK.2000.RLTS.T39664A10249370.en.Diakses pada tanggal17 Oktober 2017. 
Clarke, C., Cantley, R., Nerz, J., Rischer, H. \& Witsuba, A. 2000.Nepenthes spathulata.The IUCN Red List of Threatened Species 2000.Tersedia padan http://dx.doi.org/10.2305/IUCN.UK.2000.RLTS.T39697A10252467.en.Diakses pada tanggal 05 Januari 2019.

Clarke, C.M. 2018. Nepenthes ovata.The IUCN Red List of Threatened Species 2018.Tersedia pada http://dx.doi.org/10.2305/IUCN.UK.20181.RLTS.T39683A21844516.en.Diakses pada tanggal 19 Desember 2018.

Dariana. 2010. Keanekaragaman Kantong Semar dan Pohon Inang di Taman Wisata Alam Sicikehcikeh Kabupaten Dairi Sumatera Utara. Medan: Universitas Sumatera Utara.

Fadillah, N. N., Patana, P., Yunasfi. 2016. Keanekaragaman Nepenthes pada Kawasan Kebun Bonsai dan Sekitarnya di Cagar Alam Dolok Sibual Buali, Sumatera Utara.Jurnal Peronema Forestry Vol. 3 (2): 1-9.

Firstantinovi, E.S.dan Karjono. 2006. 'Kami justru mendorong'.Trubus, 20 November. Hlm 21.

Ginting, N. dan Lubis, J. A. 2017.Inventarisasi Nepenthes di Tapanuli Selatan.Jurnal Biologi Lingkungan, Industri, Kesehatan3(2): 183-193.

Handoyo, F. dan Sitanggang, M. 2006.Petunjuk Praktis Perawatan Kantong Semar. Jakarta: PT Agro Media Pustaka.

Hardjowigeno, S. 2007. Ilmu Tanah. Jakarta: Akademika Pressindo.

Haryani, S. 1999. Studi Keanekaragaman dan Komposisi Jenis Anggrek di Gunung Raya dalam Kawasan Cagar Alam Raya-Pasi Kabupaten Sambas.Pontianak: Fakultas Pertanian Universitas Tanjungpura.

Ludwiq, J. A. dan J. F. Reynolds. 1988. Statistical Ecology a Primer on Methods and Computing. New York: A Wiley Interscience Publication.

Mansur M. 2002. Nepenthes gymnamphora Nees. diTaman Nasional Gunung Halimun dan Penyebarannya di Indonesia. Berim Biolugi. 6(1):108-114.

Mansur M. 2006. Nepenthes, Kantong Semar yang Unik. Jakarta: Swadaya.

Mardhiana, Yakup P., Renih H. dan Dwi P.P., 2012. Karakteristik dan Kemelimpahan Nepenthes di Habitat Miskin Unsur Hara.Jurnal Lahan Suboptimal1(1): 50-56.

Mueller-Dombois, D. dan Ellenberg, H. 1974.Aims and Methods of Vegetation Ecology. New York (USA).

Muhaimin, M. Lailaty, I. Q. dan Hidayat, I. W. 2018. Keragaman tumbuhan di kawasan Hutan Lindung Gunung Tanggamus, Lampung dan upaya konservasinya.Dalam: Prosiding Seminar Nasional Masyarakat Biodiversitas Indonesia. pp. 144-150.

Nursanti dan Srirahayu.2018. Eksplorasi Kantong Semar (Nepenthes spp) di Kawasan Hulu Air Lempur Kecamatan Gunung Raya Kabupaten Kerinci.Jurnal Silva Tropika2(2): 11-16.

Odum, E. P. 1993. Dasar-Dasar Ekologi. Yogyakarta: Gajah Mada Press.

Puspitaningtyas, D. M. dan Wawangningrum, H. 2007. Keanekaragaman Nepenthes di Suaka Alam Sulasih Talang Sumatera Barat. LIPI Biodiversitas. 2(8): 152-156.

Sugiyono. 2011. Statistika untuk Penelitian. Bandung: Alfabeta.

Wiryono. 2009. Ekologi Hutan. Bengkulu: Universitas Bengkulu Press. 